\title{
Human Resource Management in the BRICS countries: a comparative study
}

\author{
Gestão de Recursos Humanos nos BRICS: estudo comparativo
}

\section{Gestion des Ressources Humaines dans les BRICS: une étude comparative}

\section{Gestión de recursos humanos de los países BRICS: un estudio comparativo}

\author{
Luciana Campos Lima ${ }^{1}$ \\ Tatiani dos Santos Zuppani \\ Maria Laura Ferranty Maclennan ${ }^{3}$
}

Received 02/03/2017; Revised and approved in 30/04/2017; Accept in 30/04/2017

DOI: http://dx.doi.org/10.20435/inter.v18i3.1514

\begin{abstract}
The objective of the study is to investigate the contextual characteristics of BRICS countries on Human Resource Management (HRM) policies and practices. For that we used secondary data analysis, such as reports, journals, and newspapers. Data is organized in order to provide logical support for the arguments presented. The main findings relate institutional environment characteristics from the education system and labour market with: (i) recruitment and selection practices; (ii) remuneration systems; (iii) training and development practices.
\end{abstract}

Key words: BRICS; remuneration systems; recruitment and selection; training and development.

Resumo: O objetivo do estudo é comparar as características contextuais dos países dos BRICS sobre as políticas e práticas de Gestão de Recursos Humanos (HRM). Para tal, a análise de dados secundários, como relatórios, revistas e informes acadêmicos foi organizada para dar suporte lógico aos argumentos. As conclusões relacionam características do ambiente institucional do sistema de ensino e mercado de trabalho com: (i) práticas de recrutamento e seleção; (ii) sistemas de remuneração; (iii) ações de treinamento e desenvolvimento.

Palavras-chave: BRICS; sistemas de remuneração; recrutamento e seleção; treinamento e desenvolvimento.

Résumé: L'objectif de l'étude est de rechercher les caractéristiques contextuelles des pays du BRICS sur la Gestion des Ressources Humaines (HRM) politiques et pratiques. Ce que nous avons utilisé pour l'analyse des données secondaires, tels que les rapports, revues et journaux. Les données sont organisées dans le but de fournir un soutien logique pour les arguments présentés. Les principales conclusions concernent características de l'environnement institutionnel du système éducatif et du marché du travail avec: (i) pratiques de recrutement et de sélection; (ii) systèmes de rémunération; (iii) pratiques de formation et de développement.

Mots clés: BRICS; systèmes de rémunération; recrutement et sélection; la formation et le développement.

Resumen: El objetivo del estudio es investigar las características contextuales de los países BRICS en políticas y prácticas de Gestión de Recursos Humanos (HRM). Para eso se utilizó el análisis de datos secundarios, como informes, revistas y periódicos. Los datos se organizan para provenir apoyo lógico a los argumentos presentados. Las principales conclusiones relacionan características del sistema educativo y mercado de trabajo con: (i) prácticas de reclutamiento y selección; (ii) sistemas de remuneración; (iii) prácticas de formación y desarrollo.

Palabras clave: BRICS; sistemas de remuneración; reclutamiento y selección; formación y desarrollo.

\section{INTRODUCTION}

It is generally agreed that Human Resource Management (HRM) policy and practices are influenced by contextual factors, such as political, legal, technological, institutional and social frameworks (KHAVUL; BENSON; DATTA, 2010; LENGNICK-HALL et al., 2009). The contextual

\footnotetext{
${ }^{1}$ Fundação Escola de Comércio Álvares Penteado (Fecap), São Paulo, São Paulo, Brasil.

2 Centro Universitário Senac São Paulo, São Paulo, Brasil.

${ }^{3}$ Centro Universitário FEl, São Bernardo do Campo, São Paulo, Brasil.
} 
approach takes a fresh look at the relationship between HRM, by considering the importance of environmental factors as the influence of public administration, trade unions, and the incidence of social and institutional influences in people management (BREWSTER; MAYRHOFER, 2012).

Resource availability and the dynamic nature of the environment and its level of complexity are recognised as having an influence on management practices and, consequently, on company performance (MORISHIMA, 1995). So the way organizations manage their human resources is institutionally rooted in national contexts and socially incorporated (MATTEN; GEPPERT, 2004). According to Brewster, Wood, and Brookes (2008), it seems there is no global consensus of best practices in the human resources area, although there is some similarity between such practices.

Conversely, the working policies and practices organizations adopt may boost their competitive advantage and this consequently has an impact on nations themselves, because this may, or may not contribute to more competitive companies. This becomes especially relevant for emerging countries (BUDHWAR; DEBRAH, 2003; LAWLER et al., 1995; STOREY; WRIGHT; ULRICH, 2009; TESSEMA; SOETERS, 2006) in order to face up to their development challenges.

An understanding of these relationships in emerging countries is also motivated by the lack of support provided by the HRM constructs coming from traditional Anglo-Saxon models, which seem not to deal with the impact of globalization on the reality of each of these countries (PRAHALAD; BHATTACHARYYA, 2011). Budhwar and Debrah (2001) also stress that management in these countries is ineffective and outdated and this denotes a barrier to good organizational results. These analyses can be applied to the BRICS group of emerging countries (Brazil, Russia, India, China and South Africa) (WILSON; PURUSHOTHAMAN, 2003), but there are very few academic publications comparing these regions (MOSTAFA; MAHMOOD, 2015). This is especially noticeable when dealing with studies that focus on Human Resource Management (HRM) in the BRICS (GARAVAN et al., 2012). We intent to contribute to this gap with the comparison of contextual characteristics on BRICS as dissimilarities impact HRM practices.

Considering that comparative knowledge of HRM practices in these countries is still in its early stages, the objective of this study is to investigate the contextual characteristics of countries belonging to the BRICS group, by identifying their relationships with each Human Resource Management policies and practices. Starting with a contextual approach, the aim is to develop a comparative study that highlights the consistent institutional and cultural structures and how they interfere in their own environment (IGNJATOVIĆ; SVETLIK, 2003). As known, there is a synergetic effect of HRM elements and its context that may create competitive advantages for both companies and nations (MORISHIMA, 1995). Lawler et al. (1995) draw attention to the lack of cross-sectional studies comparing HRM within emerging country contexts. So we aim in this study to expand the discussion about labour markets and labour force training in BRICS countries and competiveness. We consider that the latter depends on each country's production system and innovation capacity and also on the challenge of creating and developing human capital capable of meeting the demands generated by globalized processes.

\section{LITERATURE REVIEW}

Comparative studies on HRM are traditional on the field, and have been studied from several perspectives, considering contextual influences on people management. Maurice (1986) provided new angles for analysing HRM in "The social foundations of industrial power-a comparison of 
France and Germany". Based on a comparative institutional study, the author investigates the relationship between environment and companies. He shows that organizational forms and practices, qualification, structure and the organization of society are interdependent.

Whitley (1999) explains this interdependence from institutional perspective. Countries with an environment characterized by lack of confidence in their formal institutions, a State indifferent to private companies and distant from them and a scarcity of financial resources available for longterm commitments rarely foster the construction of organizational capabilities as a competitive strategy. As a consequence, those companies' human resources, tools and technologies might be easily acquired and disposed of by organizational and people management routines that are static and very complex.

On the other hand, in a context in which there is access to financing and technical interchange, developments are achieved in society by state agencies limiting the predatory price competition of large companies and by trade unions being strong enough to prevent companies from introducing strategies that allow for flexibility in staff numbers; both have a direct impact on the type of recruitment and the subsequent organizational investment in employees. There is also encouragement to improve quality and incremental innovation Training systems are high quality with a lot of incentives for both individuals and employers since they are able to improve their technical skills (WHITLEY, 1999), thus making it possible to orchestrate career plans and retain talent in organizations.

HRM, therefore, is found at the interface between the labour market environment and people management within organizations. It deals with employment policies, practices and employee recruitment, selection, development and retention activities (BOXALL; PURCELL, 2011). So the theoretical review focuses on HRM based on the contextual paradigm, because we choose to carry out an exploratory study. There is no interest in testing hypotheses, but in searching for direct discoveries and future proposals.

\section{Applying a contextual paradigm of HRM in the BRICS countries}

The contextual HRM approach makes an important modification from the managerial point of view, because it seeks for a global understanding of what is unique and different in various environments (BREWSTER; MAYRHOFER, 2012; BREWSTER; WOOD; BROOKES, 2008; MARTÍNALCÁZAR; ROMERO-FERNÁNDEZ; SÁNCHEZ-GARDEY, 2005). Prior studies involving BRICS countries are concentrated on (i) the impact of globalization process and company competiveness; (ii) interdependence between the national business context and HRM; and (iii) differences and similarities between the human resource practices among developed and developing countries. However, a comparative approach on HRM is lacking.

According to Martín-Alcázar, Romero-Fernández e Sánchez-Gardey (2005), the external environment influences and is influenced by the HRM system. In other words, labour market conditions influence the choice made by the HRM department with regard to recruiting either internally or externally (AYCAN, 2005). Likewise, a context that comprises a large population is not synonymous with high indices of qualified candidates available for selection processes. For this to be possible there is need for an efficient education system operating in the institutional environment (LUNDVALL; et al., 2002). Recruitment through informal channels occurs more frequently in countries with a limited workforce supply (AYCAN, 2005). 
In research about the educational background in the BRICS, Chaudhary et al. (2012) point out that for economists the difference between developed countries and developing countries in the 19th century was reinforced by, if not caused by sustained investment growth in human capital. Therefore educational quality, especially at the higher level, and training are crucial for constituting the production value chain, since they impact production processes. Only a qualified labour force is capable of undertaking complex tasks and adapting quickly to the changing environment (BECKER; TOMES, 1994; SCHULTZ, 1961).

Competences developed by education and training systems external to organizations will only be valued once they are allocated and used to fulfil the needs of an efficient and flexible labour market. This means that professionals may quickly migrate from one economic activity to another at little cost and reduced impact on wage fluctuations (CARNEIRO; ALMEIDA, 2008; KAPLAN, 2009).

Both the education system and labour market are influenced by the innovation level that is developed within the institutional context. This arises from new knowledge, especially technological knowledge, which is why it is related to know-how, skills and organizations' working conditions. In their turn these organizations may provide an innovative environment, especially with investment in research and development (WIR, 2014). Freeman (1995) argues that low innovation levels can be explained by factors such as ineffective educational systems for training engineers and professionals, low investment in research and development, low levels of scientific production and technology transfer, and weak relationships with industry.

We can see how education systems, training, labour market and innovation systems are complementary aspects, in view of the fact they are able to influence organizational results, since they are the constituent elements of the institutional environment to which they belong. In this sense, and based on productivity comparisons in Europe, Brewster, Wood and Brookes (2008) state that factors that affect productivity include exposure, the stock of human capital and private investment in training and innovation. Nelson (2006) concludes that quality education and pro-innovation policies can stimulate environments with high innovative performance.

Another important contextual aspect to be considered by HRM is employee compensation. Menezes-Filho, Fernandes, and Picchetti (2006) believe that salary variances in population are proportional to differences in education, since they recognise a positive link between both. Despite this, we might consider the existence of legal pronouncements that have a bearing on remuneration in the BRICS countries, since they provide evidence of the peculiarities established by the institutional environment in HRM practices.

\section{RESEARCH METHODOLOGY}

This study uses a qualitative, descriptive, exploratory and integrative approach (WAHEEDUZZAMAN, 2011) and accesses secondary sources for contextually composing HRM information about the BRICS group. To carry out the contextual analysis we decided to use World Economic Forum Global Competitiveness Index indicators (SHWAB, SALA-I-MARTIN, 2013; SCHWAB, 2015) and data from the BRICS Joint Statistical Publication (BRICS, 2014), because they integrate several managerial elements of the micro and macro environment. WEF report (SHWAB, SALA-I-MARTIN, 2013; SCHWAB, 2015) is widely recognized by academics and political decision-makers (MOSTAFA; MAHMOOD, 2015). The WEF report considers 12 pillars formed by several indicators to provide a general comparative perspective of the economic and corporate 
potential of different participant countries. BRICS (2014) is the fifth edition of a joint initiative from BRICS to consolidate data about these economies.

These indicators will be dealt with interdependently in the process of data analysis, since they mutually reinforce each other (KOVAČIČ, 2011; MARTIN, 2012). Previous comparative studies about the BRICS also used this same data as a way of interpreting and presenting results (AGGARWAL, 2013; HEINZ; TOMENENDAL, 2012; MOSTAFA; MAHMOOD, 2015).

\section{BRICS BUSINESS CONTEXT}

Between 2000 and 2012, the BRICS were responsible for 30\% of global gross domestic product (GDP) growth. By 2050 the GDP of this group, plus Mexico, Indonesia and Turkey will probably be $50 \%$ bigger than the current G7's GDP (HEINZ; TOMENENDAL, 2012). BRICS are considered to be markets in expansion, since they have been gradually opening up to more liberal economic regimes and deregulation of their economic activity (WRIGHT; VAN DE VOORDE, 2009). These characteristics, allied with a large consumer market and labour force, favour a rise in mergers and acquisitions' activity and the setting up of subsidiaries by multinational companies, even though these countries suffer from a higher level of environmental uncertainty and weaker legal systems (FARASHAHI; MOLZ, 2004; SCOTT-KENNEL; SALMI, 2008) compared to developed countries, which makes an understanding of context even more important when analysing their human resource practices.

Since HRM is strongly affected by national context, companies in different market economies adopt different approaches when managing people (FARNDALE; BREWSTER; POUTSMA, 2008). These macro environmental effects on human resource practices have already been shown empirically. Zhu, Cooper, Thomson, De Cieri, and Zhao (2013) found there to be a positive relationship between changes in the business environment, the functioning of the labour market and the use of people selection and retention practices. The environmental indicators of the BRICS countries are shown in Table 1 and are the basis for our context analysis.

Table 1 - BRICS contextual indicators

Index

\begin{tabular}{|c|c|c|c|c|c|c|c|}
\hline Institutional Context & Source & Year & BRAZIL & RUSSIA & INDIA & CHINA & $\begin{array}{r}\text { SOUTH } \\
\text { AFRICA }\end{array}$ \\
\hline Global Competitiveness Index/Position & (2) & 2014 & $4.33 / 56$ & $4.25 / 64$ & $4.28 / 60$ & $4.84 / 29^{9}$ & $4.37 / 53$ \\
\hline Unemployment Rate & (1) & $2012 / 2013$ & 6.10 & 5.50 & 5.30 & 4.10 & 25.10 \\
\hline Per capita GDP (current prices/US\$) & $(1)$ & 2013 & 11,171 & 14,604 & 1,518 & 6,768 & $7,810^{1}$ \\
\hline $\begin{array}{l}\text { Share of number of employed persons of the } \\
\text { secondary industry to total employed persons (\%) }\end{array}$ & $(1)$ & 2012 & 14. & 20.2 & 24.3 & 30.3 & 21. \\
\hline Growth rate of average annual real wage (\%) & (1) & 2012 & 5.8 & $5.30^{2}$ & nd & 9. & nd \\
\hline $\begin{array}{l}\text { Household expenditure on education, culture and } \\
\text { entertainment (\%). }\end{array}$ & (1) & 2012 & $4.10^{3}$ & 8.2 & nd & $12.70^{24}$ & $6.60^{5}$ \\
\hline Number of Internet users per 1000 inhabitants & $(1)$ & 2012 & 492 & 553 & $172^{2}$ & $458^{2}$ & $101^{8}$ \\
\hline Illiteracy rate \% (urban) & (1) & 2012 & 8.7 & $0.55^{6}$ & 14. & $3 .^{7}$ & $18.20^{1}$ \\
\hline
\end{tabular}

(1) BRICS Joint Statistical Publication 2014

(2) The Global Competitiveness Index 2014-2015

Captions in Figure 1: ${ }^{1} 2011,{ }^{2} 2013,{ }^{3} 2009,{ }^{5} 2006,{ }^{6} 2000,{ }^{8} 2010,{ }^{4}$ refer to urban population, ${ }^{7}$ World Development Indicators/Education completion and outcomes, ${ }^{9} \mathrm{excl}$. Hong Kong.

Based on a competiveness definition that considers the income increase of the population as being essential (WAHEEDUZZAMAN, 2011), analysis of the data in Table 1 shows that China 
surpasses countries like Brazil and Russia in its real growth rate in salaries and occupies the $29^{\text {th }}$ position in the global competitiveness index ranking. This is a considerable feat, since the next BRICS economy, which is South Africa, lies 53rd in the ranking.

Unemployment rates are around 4-6\%, with the exception of South Africa with its $25 \%$ rate. But when we consider employment in industry, once again China distinguishes itself with $30 \%$, practically double the figure for the last placed country in the ranking, which is Brazil with $14 \%$. Despite this, Brazil has the second biggest GDP per capita $(\$ 11,171)$, only exceeded by Russia $(\$ 14,604)$.

Generally speaking, a substantial investment in training and development activities is indicative of a low level of professional qualification resulting from the formal education system (WRIGHT; VAN DE VOORDE, 2009). Moreover, in countries in which there is a scarcity of competent labour, organizations direct higher investments to training and development programmes in order to attract the best candidates (AYCAN, 2005; GROSSMAN; HELPMAN, 1991).

We observe a great variation in illiteracy indicators among the BRICS countries. While Russia has the most favourable score (0.55), South Africa and India have the highest levels of illiteracy (18\% and $14 \%$ respectively), revealing not only the heterogeneity between the BRICS, but also pointing to the challenges faced by companies located in those environments in their search for qualified people and ways of retaining them (table 1).

Considering HRM to be a product of the business environment (BJÖRKMAN; FEY; PARK, 2007; BREWSTER; WOOD; BROOKES, 2008), the next topic examines how HRM practices are operationalized given the cultural and institutional peculiarities of each component of the BRICS group.

\subsection{HRM context in the BRICS countries}

The indicators in Table 2 are related to HRM in the BRICS countries. They show the 'share of public spend on education', 'higher education and training', 'labour market efficiency' and the 'innovation' indicators.

Table 2 - Human resource indicators of the BRICS countries

\begin{tabular}{|c|c|c|c|c|c|c|c|}
\hline Local HR indicators & Source & Year & BRAZIL & RUSSIA & INDIA & CHINA & $\begin{array}{l}\text { SOUTH } \\
\text { AFRICA }\end{array}$ \\
\hline Share of public spend on education as \% of GDP & (1) & $2012 / 2013$ & 5.3 & 4.3 & 3.3 & 4.3 & 6.8 \\
\hline Higher Education and Training & $(2)$ & $2013 / 2014$ & $4.22 / 72$ & $4.66 / 47$ & $3.88 / 91$ & $4.23 / 70$ & $3.94 / 89$ \\
\hline Labor Market efficiency & (2) & $2013 / 2014$ & $4.13 / 92$ & $4.31 / 72$ & $4.08 / 99$ & $4.63 / 34$ & $3.93 / 116$ \\
\hline Innovation & $(2)$ & $2013 / 2014$ & $3.42 / 55$ & $3.13 / 78$ & $3.62 / 41$ & $3.89 / 32$ & $3.64 / 39$ \\
\hline
\end{tabular}

(1) BRICS Joint Statistical Publication 2014

(2) The Global Competitiveness Index 2014-2015

These data support the analysis of the constituent elements of HRM in the BRICS countries analysed in this study and presented in the following topics.

\subsubsection{Labour Market and HRM in the BRICS countries}

We see an alignment in Brazil between labour market indicators (4.13) and higher education and training (4.22), showing that the country's institutions are performing at a median level. These data are coherent with the argument put forward in the work of Ricardo, Costa, and 
Ferreira (2013), who classify specialist labour in the labour market in the country as being scarce. Furthermore, those professionals who have special competences are being head-hunted by other countries, especially the Europeans. Finally, the unemployment rate has remained low over recent years, which sharpens the dispute for good professionals.

Employment and labour practices in Russia are fairly homogenous, even after the transition of the economic regime, which weakened state regulation over company policies. Public investment in education (4.30) is similar to the higher education and training indicator (4.66), since all of the indicators seem to point to a partially good quality level. Since people selection processes are carried out by line managers who are seeking to fill gaps as quickly as possible regardless of HRM guidelines (BIZYUKOV, 2005; SHULZHENKO, 2012), it is possible that they choose insufficient professionals with adequate qualifications to fil the positions. In this environment the ones who stand out from a mass of mediocre candidates who come from an average educational system may profit from higher remuneration.

Cultural values in India weigh heavily on human resource practices (WRIGHT; VAN DE VOORDE, 2009), including the placing of people in the labour market. The caste people are born into determines their social strata, which has both an explicit and implicit impact on the recruitment and selection of people. This possibly explains the fact that among the BRICS countries, India makes the smallest public investment percentage-wise in education (3.30), in higher education (3.88) and in training (4.08).

On the other hand, the labour market efficiency indicator for China is the highest among the BRICS countries (4.63), but the quality of the workforce available is not as great as its volume. This explains part of the scarcity of competences, which drives the use of practices for retaining professionals (CAI; MORRIS; CHEN, 2011). This characteristic may also be a remnant of the past, since during the Marxist regime period job generation was theoretically the responsibility of the Chinese government, which had to allocate all graduates into the labour market. Therefore, the Chinese concept of career was defined and directed by the State (ZHOU; ZHANG; LIU, 2012).

For Bernstein (2011), one of the main challenges to the economic growth of South Africa depends on reconciling high labour standards with the development of qualifications, good remuneration and a protection system for workers. Turok (2010) estimates that there is a shortage of around 100,000 competent people, which is fairly insignificant when compared with an unemployment rate of more than 4 million people. Even given the evidence of the increase in employment relations institutions with trade unions that are not linked to the State, we find an increase in the numerical and temporal 'flexibilization' process governing workers by way of sub-contracting and outsourcing. This is leading to a deterioration in employment standards, social protection and growing precariousness in the labour market (HORWITZ, 2012; STOREY; WRIGHT; ULRICH, 2009). These factors perhaps explain the fact that the efficiency of the labour market in South Africa (3.93) is the lowest in the BRICS countries.

\subsubsection{Education System, Training and HRM remuneration in the BRICS countries}

Since the theory deals with the relationship between education and salary (MenezesFilho; FERNANDES; PICCHETTI, 2006) this topic will include issues referring to compensation practices also. Costa (2012) argues that HRM in organizations in Brazil is capable of diagnosing and identifying training and development needs and has the ability to plan, organize and conduct 
their operationalization. It is less capable, however, of evaluating the investment needed for training and developing professionals. So, in order to maintain high levels of productivity and high volumes of investment in the private sector, HRM's capacity to evaluate the return on the amount spent on development programmes needs to be improved. We have already discussed the fact that Brazilian investment in the professionalization process via the education system is considered to be partially good (4.22), but lower than Russia's (4.66) and China's (4.23). Negri and Cavalcante (2014) argue that productivity in Brazil is severely impaired by a lack of qualified professionals, which points to the importance of this dimension.

Remuneration practice is related to legal determinations that provide support for the functioning of this system in companies. Some types of remuneration do not have specific legislation and others have incomplete or out-of-date legislation. Under these circumstances there is no legislation with regard to bonuses, shareholdings and skills and competence-based pay making it possible to adapt remuneration tools to fit the interests of each organization. There is also no detailed legislation about the incidence, or otherwise, of taxes on some of the remuneration practices; it is up to trade unions to decide on their application by way of the collective union agreement (THEOTÔNIO; REIS NETO; LOPES, 2013).

In Russia, there are two types of training; training for the newly hired and technical training for blue-collar workers (non-managers) and white-collar workers (managers) in various training practices (BIZYUKOV, 2005), which are increasingly characterized by Western HRM techniques (GURKOV; SETTLES, 2013). Russian HR development strategy allows us to infer that they are aiming to compensate the investment made by the current education system (4.66) and reduced public investment (4.30) for professional qualification. This is because they allocate their resources in a way that is spread across the three professional profiles: the recently hired, specialists and generalists.

The practices that compose their remuneration system are characterized by an official guarantee of just a small part of the payment. But companies can reduce or increase salaries without negotiating beforehand with employees (SHULZHENKO, 2012). After the transition from a planned economy in the 2000s, Russia went into economic recession, with a drop of $23 \%$, on average, in industrial production. As a survival strategy, companies adopted a 30\% reduction in salaries and while they avoided dismissing people, they encouraged their employees to ask for voluntary leave of absence without pay. In the 2009-2010 period, the total number of people on voluntary leave without pay reached $3 \%$ of the labour force, thus masking the real unemployment rate. The economic situation improved in the 2010-2011 period (GURKOV; SETTLES, 2013). Despite the fact that the labour market efficiency index (4.31) only loses out to China (4.63), it is difficult to understand it as being something that is favourable, given the signs of strong government intervention, as described.

China's rapid economic and technological development created requirements for new and higher skill levels (SHEN; D'NETTO, 2012). That does not seem to resemble in terms of labour quality, just in quantity. In other words, public investment in education (4.30) is less than in Brazil (5.30) and in higher education and training is 4.23 , which is only partially good. Despite China carrying out extensive training (LI; ZHAO; LIU, 2006), the focus of such training in the workplace continues to concentrate on technical skills (LI; SHELDON, 2010). These data are explained when we observe the higher education and training indicator (4.23). Despite this, the education system in China provides access for all and not just for key professionals (CAI; MORRIS; CHEN, 2011).

INTERAÇÕES, Campo Grande, MS, v. 18, n. 3, p. 69-82, jul./set. 2017. 
The new market economy and regulations allow companies to finance growth and reward productive employees (LI; ZHAO; LIU, 2006). Managers can choose special monetary rewards to motivate workers in accordance with their performance. Rewards are not based on individual performance and the distribution of bonuses to all workers, regardless, does not lead to increases in productivity (SHEN; D'NETTO, 2012; ZHU et al., 2013).

Racial segmentation in the labour market in South Africa still subsists as a legacy of apartheid and has an impact on access to technological knowledge at the higher level (ERASMUS; SCHENK; SWANEPOEL, 2008). This may explain why the country's public investment indicator in education is the highest of all the BRICS countries (6.80), but the higher education level cannot even be classified as average, because it tends towards being of a poor quality (higher education and training at 3.94), despite attempts to improve the compulsory education system.

Results from such investments may take a long time to appear (HORWITZ, 2012). Just 15 out of every 500 children in South Africa enter university post-graduate schools. This is probably the reason why most of the companies invest an amount of their wage-roll on training for all positions in an egalitarian way (ERASMUS; SCHENK; SWANEPOEL, 2008). Turok (2010) agrees that the lack of technical and professional training is one of the main obstacles to infrastructure projects being carried out.

In relation to other BRICS countries, India has the lowest level of formal education (3.88), which is in line with the professionalization process that started at the end of the 1990s. We saw an effort on the part of HRM at the time, to ensure the development of employee competences and training and there were signs of a movement towards performance-related salaries and promotions (AZMI, 2011).

Trade union organization and government had a very strong influence on the determination of salary levels in that country. However, as from the 1980s the globalization of markets and the access of Indian students to foreign universities generated new forms of thinking and increased the flexibility of salary relations, thus strengthening the relationship between pay and performance. However, we can still observe significant differences between HR performance in major corporations that assess performance and recommend salary increases based on the same and the reality we see in small companies and with workers in rural areas (SPARROW; BUDHWAR, 1997).

\section{FINAL CONSIDERATIONS}

Analysis of the relationships between the contextual characteristics and the various HRM practice formats of BRICS country companies allows for a resignification of HRM studies. Investigations of people management policies and practices limited to organizations are incapable of offering academics and practitioners the full dimension of their social importance. This is because the main finding of this study was the presentation of an initial analysis and inference path that relates aspects of the macro-environment with the micro-environment. As a result, it came up with an interpretation of how much the international HRM and HRM fields that have developed nationally seem to share a short-sighted view of the subject.

The analysis and inference path between the characteristics and elements of the institutional environment is based on relationships of cause and effect between the labour market and education system and: (i) recruitment and selection practices; (ii) the remuneration 
system; (iii) people training and development practices, which are strongly influenced by the legal context.

Convergent points were identified between the constituents of the BRICS members. Those countries in which there has been a great change in their context, especially as far as concerns economic and political aspects, such as China and Russia, show that their HRM practices are considerably influenced and modified as a result of contextual transformations. Divergent points occur in the global-local dilemma; despite the fact that nations are influenced by the AngloAmerican management standards introduced by multinationals, they still preserve HRM practices whose structures are strongly based on cultural aspects, such as Brazil, India and South Africa.

These findings are in line with the discussions about the convergent and divergent forces operating in the globalization process. On the one hand, management is influenced by the characteristics of the institutional environment (size, ownership status, industry, competitiveness of the market and resource availability) and, on the other, it is also influenced by the assumptions of the competitive international market (AYCAN, 2005).

We suggest that a longitudinal study be carried out, which should be developed with researchers representing each of the BRICS countries; joint quantitative production should be used to validate qualitative inferences. As far as concerns the study's limitations, it was carried out on the basis of a snapshot in time, which did not allow for a more in-depth analysis based on a longitudinal study. This is because, in addition to there being a dearth of information about HRM development over the years in BRICS countries, scientific production combining both a macro and micro perspective is limited. Because this is an exploratory study, non-longitudinal analysis is recognized as being a limitation but not a restriction.

Another limitation of the method was the use of data from the WEF report (SHWAB, SALA-I-MARTIN, 2013; SCHWAB, 2015). There is criticism of the methodology used for constituting the report and about the way it is used, both in academic and commercial fields (CARVALHO; DI SERIO; VASCONCELLOS, 2012). The non-existence of another, more reliable data source ends up supporting the choice of this particular source.

The final consideration regarding limitations was that it was not possible to discuss issues related to innovation, since the HRM bibliography has very little information about the subject, except in reference to India.

\section{Implications}

We believe we have expanded the discussion about preparing the labour force within the context of the BRICS labour market. Considering that the competiveness of a nation depends on its production and innovation capacity, the challenge is to develop and create its human capital in such a way as to serve the requirements of international markets. So it is possible that the developers of public policies that deal with the institutional aspects discussed can make use of the analytical path we travelled down.

Company managers now have access to analyses and interpretations that can help them when taking decisions that involve the way in which people are managed in different regions in the world. Academics, especially those working in the IHRM and HRM fields, are offered an alternative proposal for analysing the processes that constitute these particular fields. 


\section{REFERENCES}

AGGARWAL, R. Adjusting to BRICs in glass houses: replacing obsolete institutions and business models. Thunderbird International Business Review, v. 55, n. 1, p. 37-54, 2013.

AYCAN, Z. The interplay between cultural and institutional/structural contingencies in human resource management practices. The International Journal of Human Resource Management, v. 16, n. 7, p. 10831119,2005

AZMI, F. T. Strategic human resource management and its linkage with HRM effectiveness and organizational performance: evidence from India. The International Journal of Human Resource Management, v. 22, n. 18, p. 3888-3912, 2011.

BECKER, G. S.; TOMES, N. Human capital and the rise and fall of families Human Capital: a theoretical and empirical analysis with special reference to education. 3. ed. Illinois: The University of Chicago Press, 1994. p. 257-298.

BERNSTEIN, H. A dinâmica de classe do desenvolvimento agrário na era da globalização (Agricultural development class dynamics in the age of globalization). Sociologias, v. 13, n. 27, p. 52-81, 2011.

BIZYUKOV, P. Sluzhby personala- upravlencheskaya periferiya. In: KABALINA, V. I. (Ed.). Praktiki upravleniya personalom na sovremennykh rossiyskikh predpriyatiyakh. Moscow: ISITO, 2005.

BJÖRKMAN, I.; FEY, C. F.; PARK, H. J. Institutional theory and MNC subsidiary HRM practices: evidence from a three-country study. Journal of International Business Studies, v. 38, n. 3, p. 430-446, 2007.

BOXALL, P.; PURCELL, J. Strategy and human resource management. 3. ed. Basingstoke: Palgrave Macmillan, 2011.

BREWSTER, C.; MAYRHOFER, W. Handbook of research on comparative human resource management. Lisboa: Edward Elgar Publishing, 2012.

BREWSTER, C.; WOOD, G.; BROOKES, M. Similarity, isomorphism or duality? Recent survey evidence on the human resource management policies of multinational corporations. British Journal of Management, v. 19, n. 4, p. 320-342, 2008.

BRICS: Brazil, Russia, India, China, South Africa. Joint Statistical Publication: 2014. Rio de Janeiro: IBGE, 2014. 212 p.

BUDHWAR, P. S.; DEBRAH, Y. Rethinking comparative and cross-national human resource management research. The International Journal of Human Resource Management, v. 12, n. 3, p. 497-515, 2001. doi: 10.1080/713769629

CAI, Z.; MORRIS, J. L.; CHEN, J. Explaining the human resource management preferences of employees: a study of Chinese workers. The International Journal of Human Resource Management, v. 22, n. 16, p. 3245-3269, 2011.

CARNEIRO, L. P.; ALMEIDA, M. H. T. D. Definindo a arena política local: sistemas partidários municipais na federação brasileira. Dados, Rio de Janeiro, v. 51, n. 2, p. 403-432, 2008.

CARVALHO, L. C. D.; DI SERIO, L. C.; VASCONCELLOS, M. A. D. Competitiveness of nations: review of the metric used by the World Economic Forum. Revista de Administração de Empresas, v. 52, p. 421-434, 2012.

CHAUDHARY, L.; MUSACCHIO, A.; NAFZIGER, S.; YAN, S. Big BRICs, weak foundations: The beginning of public elementary education in Brazil, Russia, India, and China. Explorations in Economic History, v. 49, n. 2, p. 221-240, 2012.

COSTA, R. M. Os programas de treinamento, desenvolvimento e educação corporativa e o nível de maturidade em gestão de pessoas: [recurso eletrônico]: um estudo baseado no People Capability Maturity Model (P-CMM). 262f. 2012. Dissertação (Mestrado em Administração de Empresas)- Pontifícia Universidade Católica do Rio de Janeiro (PUC-Rio), RJ, 2012.

ERASMUS, B.; SCHENK, H.; SWANEPOEL, B. South African human resource management: theory \& practice. [s.I.]: Juta and Company Ltd, 2008. 
FARASHAHI, M.; MOLZ, R. A Framework for multilevel organization analysis in developing countries. International Journal of Commerce and Management, v. 14, n. 1, p. 59-78, 2004.

FARNDALE, E.; BREWSTER, C.; POUTSMA, E. Coordinated vs. liberal market HRM: the impact of institutionalization on multinational firms. The International Journal of Human Resource Management, v. 19, n. 11, p. 2004-2023, nov. 2008.

FREEMAN, C. The National System of Innovation' in historical perspective. Cambridge Journal of Economics, v. 19, n. 1, p. 5-24, 1995.

GARAVAN, T. N.; CARBERY, R.; ARDICHVILI, A.; ZAVYALOVA, E.; MININA, V. Human capital development: comparative analysis of BRICs. European Journal of Training and Development, v. 36, n. 2/3, p. 213-233, 2012.

GROSSMAN, G. E.; HELPMAN, E. Innovation and Growth in the Global Economy. Cambridge: MIT Press, 1991.

GURKOV, I.; SETTLES, A. A dominant archetype of the HRM system in Russian industrial companies in post-recession times. The International Journal of Human Resource Management, v. 24, n. 19, p. 36303643, 2013.

HEINZ, D. B.; TOMENENDAL, M. The Emerging market hype-putting market size and growth in BRIC countries into perspective. Critical perspectives on international business, v. 8, n. 3, p. 241-258, 2012.

HORWITZ, F. M. Evolving human resource management in Southern African multinational firms: towards an Afro-Asian nexus. The International Journal of Human Resource Management, v. 23, n. 14, p. 29382958, 2012.

IGNJATOVIĆ, M.; SVETLIK, I. European HRM clusters. EBS review, Autumn, n. 17, p. 25-39, 2003.

KAPLAN, D. S. Job creation and labor reform in Latin America. Journal of Comparative Economics, v. 37, n. 1, p. 91-105, 2009.

KHAVUL, S.; BENSON, G. S.; DATTA, D. K. Is internationalization associated with investments in HRM? A study of entrepreneurial firms in emerging markets. Human Resource Management, v. 49, n. 4, p. 693713, 2010.

KOVAČIČ, A. Industrial enlargement and competitiveness index. Zagreb International Review of Economics and Business, v. 14, n. 2, p. 15-50, 2011.

LAWLER, J. J.; JAIN, H. C.; VENKATA RATNAM, C. S.; ATMIYANANDANA, V. Human resource management in developing economies: a comparison of India and Thailand. The International Journal of Human Resource Management, v. 6, n. 2, p. 319-346, 1995. DOI: 10.1080/09585199500000022

LENGNICK-HALL, M. L.; LENGNICK-HALL, C. A.; ANDRADE, L. S.; DRAKE, B. Strategic human resource management: the evolution of the field. Human Resource Management Review, v. 19, n. 2, p. 64-85, 2009.

LI, Y.; SHELDON, P. HRM lives inside and outside the firm: employers, skill shortages and the local labour market in China. The International Journal of Human Resource Management, v. 21, n. 12, p. 2173-2193, 2010.

LI, Y.; ZHAO, Y.; LIU, Y. The relationship between HRM, technology innovation and performance in China. International journal of manpower, v. 27, n. 7, p. 679-697, 2006.

LUNDVALL, B.-Å.; JOHNSON, B.; ANDERSEN, E. S.; DALUM, B. National systems of production, innovation and competence building. Research Policy, v. 31, n. 2, p. 213-231, 2002. DOI: http://dx.doi.org/10.1016/ S0048-7333(01)00137-8

MARTIN, B. R. The evolution of science policy and innovation studies. Research Policy, v. 41, n. 7, p. 12191239, 2012. DOI: http://dx.doi.org/10.1016/j.respol.2012.03.012

MARTÍN-ALCÁZAR, F.; ROMERO-FERNÁNDEZ, P. M.; SÁNCHEZ-GARDEY, G. Strategic human resource management: integrating the universalistic, contingent, configurational and contextual perspectives. The International Journal of Human Resource Management, v. 16, n. 5, p. 633-659, may 2005. 
MATTEN, D.; GEPPERT, M. Work systems in heavy engineering: the role of national culture and national institutions in multinational corporations. Journal of International Management, v. 10, n. 2, p. 177-198, 2004.

MAURICE, M. La qualification comme rapport social: à propos de la qualification comme mise en forme du travail. In: SALAIS, R.; THÉVENOT, L. (Eds.). Le travail, marche'. Aix-en-Provence: Laboratoire d'economie et de sociologie du travail, 1986. p. 179-192.

MENEZES-FILHO, N. A.; FERNANDES, R.; PICCHETTI, P. Rising human capital but constant inequality: the education composition effect in Brazil. Revista Brasileira de Economia, v. 60, p. 407-424, 2006.

MORISHIMA, M. Embedding HRM in a social context. British Journal of Industrial Relations, v. 33, n. 4, p. 617-640, 1995.

MOSTAFA, G.; MAHMOOD, M. The rise of the BRICS and their challenge to the G7. International Journal of Emerging Markets, v. 10, n. 1, 2015.

NEGRI, F. D.; CAVALCANTE, L. R. Produtividade no Brasil: desempenho e determinantes. Brasilia: ABDI, 2014.

NELSON, R. Sistemas Nacionais de Inovação: retrospecto de um estudo. In: NELSON, R. (Ed.). As fontes do crescimento econômico. Campinas: Unicamp, 2006. p. 427-467 (Clássicos da Inovação).

PRAHALAD, C.; BHATTACHARYYA, H. How to be a truly global company. Strategy+ Business Magazine, $\mathrm{n}$. 64, aug. 2011.

RICARDO, R. G.; COSTA, D. V. F.; FERREIRA, V. C. P. Recruitment and selection in organizations in the perception of the manager as internal customer: a case study. Revista de Administração da UEG, v. 4, n. 2, p. 10, 2013.

SCHULTZ, T. Investment in human capital. The American economic review, v. 51, n. 1, p. 1-17, mar. 1961.

SCOTT-KENNEL, J.; SALMI, A. The rise of the big emerging markets of Brazil, Russia, India, and China: implications for international business teaching in the next decade. Journal of Teaching in International Business, v. 19, n. 2, p. 142-166, 2008.

SHEN, J.; D'NETTO, B. Impact of the 2007-09 global economic crisis on human resource management among Chinese export-oriented enterprises. Asia Pacific Business Review, v. 18, n. 1, p. 45-64, 2012.

SHULZHENKO, E. Human resource management and labour relations in post-transitional Russia. Discussion Paper. Berlin: WZB Berlin Social Science Center, 2012.

SPARROW, P. R.; BUDHWAR, P. S. Competition and change: mapping the indian HRM recipe against worldwide patterns. Journal of world business, v. 32, n. 3, p. 224-242, 1997. doi: http://dx.doi.org/10.1016/ S1090-9516(97)90009-2

STOREY, J.; WRIGHT, P. M.; ULRICH, D. The Routledge companion to strategic human resource management. London: Routledge, 2009. 530p.

TESSEMA, M. T.; SOETERS, J. L. Challenges and prospects of HRM in developing countries: testing the HRM - performance link in the Eritrean civil service. The International Journal of Human Resource Management, v. 17, n. 1, p. 86-105, 2006. doi: 10.1080/09585190500366532

THEOTÔNIO, K. S.; REIS NETO, M. T.; LOPES, S. A. A. Remuneração no Brasil: uma análise segundo os aspectos legais. In: ENCONTRO DA ANPAD- EnANPAD, 37., 7-11 set. 2013, Rio de Janeiro. Annals... Rio de Janeiro: ANPAD, 2013.

TUROK, I. Towards a developmental state? Provincial economic policy in South Africa. Development Southern Africa, v. 27, n. 4, p. 497-515, 2010.

WAHEEDUZZAMAN, A. N. M. Competitiveness and convergence in $\mathrm{G} 7$ and emerging markets. Competitiveness Review, v. 21, n. 2, p. 110-128, 2011.

WHITLEY, R. Divergent capitalisms: the social structuring and change of business systems. [s.l.]: Oxford University Press, 1999. 
WILSON, D.; PURUSHOTHAMAN, R. Dreaming With BRICs: the path to 2050. New York: GSGE, 2003. 23p. WIR. World Investment Report 2014: investing in the SDGs, an action plan. New York and Geneva: United Nations, 2014.

WORLD ECONOMIC FORUM (WEF). The Global Competitiveness Report 2014-2015. Geneve: WEF, 2014. p. 3-48.

WRIGHT, P.; VAN DE VOORDE, K. Multilevel issues in IHRM: mean differences, explained variance, and moderated relationships. In: SPARROW, Paul (Ed.). Handbook of international human resource management: integrating people, process, and context. Chichester: Wiley, 2009. p. 29-40.

ZHOU, Y.; ZHANG, Y.; LIU, J. A hybridism model of differentiated human resource management effectiveness in Chinese context. Human Resource Management Review, v. 22, n. 3, p. 208-219, 2012.

ZHU, C. J.; COOPER, B. K.; THOMSON, S. B.; DE CIERI, H.; ZHAO, S. Strategic integration of HRM and firm performance in a changing environment in China: the impact of organisational effectiveness as a mediator. The International Journal of Human Resource Management, v. 24, n. 15, p. 2985-3001, 2013.

\section{About the authors:}

Luciana Campos Lima: Holds a PHD in Business Administration by University of São Paulo, and is a professora at Fundação Escola de Comércio Álvares Penteado (Fecap). E-mail: lucamposlima@hotmail.com

Tatiani dos Santos Zuppani: Holds a PHD in Business Administration by FEA USP. Professora at Centro Universitário Senac São Paulo. E-mail: tszuppani@gmail.com

Maria Laura Ferranty Maclennan: Holds a PhD in Business Administration by FEA USP, a Master's degree in Administration by ESPM and graduated in Business Administration from FEA USP. E-mail: laura.maclennan@usp.br 